\title{
A further physiological role for naturally occurring trypsin inhibitors: the evidence for a trophic stimulant of the pancreatic acinar cell
}

\author{
R. N. MELMED 1 AND I. A. D. BOUCHIER \\ From the Department of Medicine, Royal Free Hospital, London
}

SUMMARY The oral ingestion of naturally occurring purified trypsin inhibitors from soybean, ovomucoid, and bovine pancreas has been demonstrated to be a potent stimulus to pancreatic digestive enzyme synthesis. This effect may be so marked as to lead to impairment of growth in the rat and chicken through the faecal loss of essential amino acids. This is thought to be due to the markedly potentiated secretion of pancreatic digestive enzyme protein overwhelming the normal digestive capacity of the gastrointestinal tract and resulting in a pancreatogenous protein-losing enteropathy.

Experimental evidence is presented to suggest that this response to the trypsin inhibitors requires the mediation of the gastrointestinal tract and is independent of vagal innervation to the pancreas. The most satisfactory hypothesis would favour the release of a trophic stimulus from the intestinal mucosa (possibly pancreozymin-cholecystokinin) to the acinar cell of the pancreas in response to the presence of the trypsin inhibitor in the bowel lumen.

It is suggested that a primary function of the endogenously secreted pancreatic trypsin inhibitor may be to potentiate enzyme synthesis by the acinar cell, providing an important stimulus for the repletion of the digestive enzymes. Some of the potential physiological and clinical implications of such a mechanism are discussed.

In 1917 Osbourne and Mendel observed that the poor nutritive value of raw soybean meal could be improved by heating. The discovery of a heat-labile trypsin inhibitor in raw soybean (Ham and Sanstedt, 1944; Bowman, 1944) was incriminated as the cause of the poor growth in rats fed on raw soybean meal through interfering with normal intestinal tryptic activity (Riesen, Clandinin, Elvehjem, and Cravens, 1947; Melnick, Oser, and Weiss, 1946). This hypothesis was supported by the observation of an increased faecal nitrogen excretion after feeding raw soybeans. However, that inhibition of proteolysis per se could not adequately account for these observations was shown by Klose, Hill, Greaves, and Fevold (1948) and Westfall, Bosshardt, and Barnes (1948) who demonstrated inhibition of growth in animals fed trypsin inhibitor with predigested protein.

It was subsequently found (Chernick, Lepkovsky, and Chaikoff, 1948; Lyman, 1957; Lyman and

${ }^{1}$ Present address: Courtauld Institute of Biochemistry Middlesex Hospital Medical School, London, W1.
Lepkovsky, 1957; Haines and Lyman, 1961) that animals and poultry fed on a diet containing soybean trypsin inhibitor developed large pancreases with an increased capacity to secrete pancreatic digestive enzymes. These authors suggested that the increased faecal nitrogen loss originated from the enhanced pancreatic secretions, representing a form of pancreatogenous protein-losing enteropathy. Further studies pointing to the primary role of the pancreas in the pathogenesis of this condition were provided by Booth, Robbins, Ribelin, and Deeds (1960), by Borchers (1961), and by Khayambashi and Lyman (1966). These authors demonstrated a reversal of growth inhibition by supplementary feeding of essential amino acids (especially threonine, valine, and methionine); however, pancreatic enlargement remained unchanged.

The following experiments were designed to clarify the role of the trypsin inhibitor in the development of the pancreatic enlargement and to determine the manner in which these substances may act on the pancreas. 


\section{MATERIAL AND METHODS}

Male Sprague-Dawley rats were used in all the experiments. Unless otherwise stated the animals were fed a standard laboratory 41B diet. ${ }^{1}$ In all experiments involving soybean, the soybean flour ${ }^{2}$, heated or raw, was mixed with the 41B diet in the ratio of $39 \mathrm{~g}$ soybean flour to $45 \mathrm{~g} 41 \mathrm{~B}$. This mixture is termed the 'test diet' and the content of protein, fat, and calories for each diet is presented in Table I. It was calculated that the soybean flour contributed $80 \%$ of the protein and $85 \%$ of the fat in the test diet.

\section{TABLE I}

PERCENTAGE COMPOSITION OF PROTEIN, FAT, AND CALORIE CONTENT OF DIETS

\begin{tabular}{llll} 
& Soya Flour & 41 B & Test Diet \\
\hline Protein & 41 & 16 & 27 \\
Fat & 19 & 3 & 8.8 \\
Cal $/ \mathrm{g}$ & 4.13 & 3.00 & 3.7
\end{tabular}

The purified trypsin inhibitors were obtained from commercial sources. The soybean inhibitor ${ }^{3}$ was the grade 1 variety, purified by the method of Kunitz (1945) and had an activity equivalent to the three times crystallized soybean trypsin inhibitor. The activity, measured spectrophotometrically, was 9,500 units/mg using Nbenzoye-L-arginine ethyl ester hydrochloride as substrate. The ovomucoid inhibitor ${ }^{4}$ was designated type 11-0, 1 $\mathrm{mg}$ inhibiting $0.9 \mathrm{mg}$ of trypsin. The bovine pancreatic trypsin inhibitor was obtained as the compound Trasylol $^{5}$, each $5 \mathrm{ml}$ having a potency of $25,000 \mathrm{Kiu}$ and containing $4 \mathrm{mg}$ protein (personal communication from the manufacturers).

Termination of all experiments was preceded by a fast of 16 to 24 hours and the animals were sacrificed in an ether chamber. Total pancreatectomies were performed on all animals.

For the analysis of the pancreas, the whole organ was first freeze-dried to constant weight. Thereafter 20 to $30 \mathrm{mg}$ of dried tissue was weighed on a precision balance, cut into small pieces with a sharp scalpel blade and homogenized in $2.5 \mathrm{ml}$ of $0.9 \%$ saline for three to four minutes using a teflon homogenizer. The homogenate was spun at 2,500 rpm for 30 minutes, the supernatant decanted, and suitable volumes (approximately 10 to $20 \mu$ l) were taken from each sample for protein and amylase estimations. The protein was estimated by Miller's (1959) modification of the Lowry technique. Amylase activity was estimated by Henry and Chiamori's assay (1960). Amylase specific activity has been expressed as units of activity per milligram pancreatic protein. Amylase capacity was calculated as the total amylase content of the gland. All tissue was stored at $-20^{\circ} \mathrm{C}$. Sections taken from three pancreases in each of the heated and raw soya-fed groups were fixed in calcium-formol solution

'The 'Oxoid' Division, Oxo Ltd, London, SE1.

'Soya Foods Ltd, London, EC3.

'Serevac Laboratories (Pty.) Ltd., Berk., England.

SSigma Chemical Company, USA.

'FBA Pharmaceuticals Ltd, Sussex, England. and stained with haematoxylin and eosin. There were no pathological features seen in these pancreases.

\section{EXPERIMENTS AND RESULTS}

INFLUENCE OF SOYBEAN-SUPPLEMENTED DIET ON RAT PANCREAS AND LIVER Two groups of six rats each were fed a test diet supplemented with heated and raw soybean meal respectively for six weeks. In this experiment the liver was also removed, swabbed, and weighed at the termination of the experiment.

The pancreas was found to be significantly larger in the raw soybean-fed group (Fig. 1). For any given

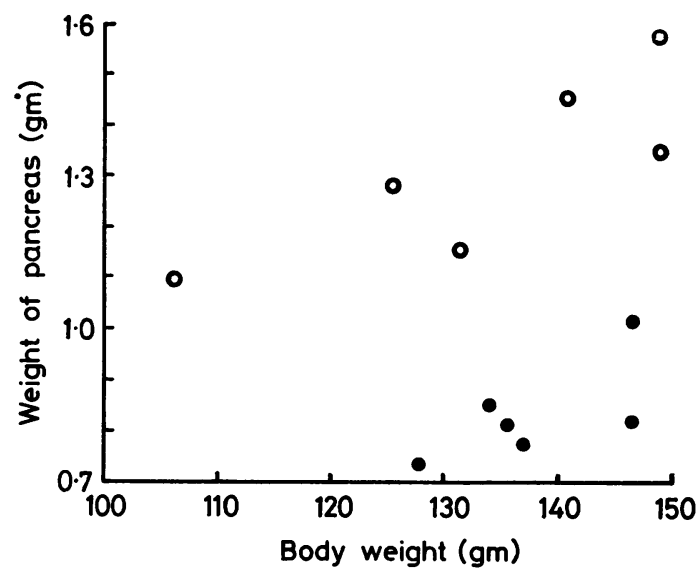

FIG. 1. Relationship between pancreatic and body weight in rats fed on heated $(\bigcirc)$ and raw (O) soybean dietary supplements.

\section{TABLE II}

WEIGHTS OF PANCREAS AND LIVER IN TWO GROUPS OF SIX RATS FED HEATED AND RAW SOYBEAN ${ }^{1}$

\begin{tabular}{|c|c|c|}
\hline & \multicolumn{2}{|l|}{ Soybean } \\
\hline & Heated & Raw \\
\hline $\begin{array}{l}\text { Pancreas (mg) } \\
\text { Liver (g) }\end{array}$ & $\begin{array}{l}603( \pm 55) \\
6 \cdot 789( \pm 0.849)\end{array}$ & $\begin{array}{l}960( \pm 78) \\
6.849( \pm 1 \cdot 246)\end{array}$ \\
\hline
\end{tabular}

${ }^{1}$ Results expressed as mean \pm 1 SD per $100 \mathrm{~g}$ body weight.

body weight the pancreases of rats fed on the raw soybean supplement were $20 \%$ to $40 \%$ larger than those of the control group fed the heated soybeansupplemented diet. These measurements represent the wet tissue weight, as the mean pancreatic water content of both groups was found to be the same. The results of the organ weights corrected for differences in body weight are presented in Table II. Although the weight of the liver was uninfluenced by 
the diets, the mean pancreatic weight of the raw soybean-fed group was significantly greater than that of the control group $(\mathrm{P}<0.0001)$.

EFFECT OF A DIETARY SUPPLEMENT TRYPSIN INHIBITOR ON THE RAT PANCREAS. Four groups of six rats each were fed an identical basal test diet containing heated soybean meal. The animals were changed from the 41B diet to the test diet at the start of the experiment. To each of three groups was added a daily supplement of purified trypsin inhibitor from soybean $(0.6 \% \mathrm{w} / \mathrm{w})$, ovomucoid $(0.6 \% \mathrm{w} / \mathrm{w})$, and bovine pancreas $(0.043 \% \mathrm{w} / \mathrm{w})$ respectively. To ensure complete ingestion of the daily ration the diet was fed in gradually increasing increments to the groups, starting from a level which was obviously inadequate for the growth needs of the rats. Thus for the first four days the mean weight of each group remained the same. Thereafter with increasing diet, weight gain was very rapid. The experiment was concluded on the ninth day. The pancreases were analysed for amylase capacity and specific activity.

The results of this experiment are presented in Table III. The differences in amylase capacity and

\section{TABLE III}

INFLUENCE OF PURIFIED TRYPSIN INHIBITOR ON PANCREATIC WEIGHT, AMYLASE CAPACITY, AND SPECIFIC ACTIVITY EXPRESSED PER $100 \mathrm{~g}$ BODY WEIGHT $( \pm$ SD)

\begin{tabular}{llll} 
Group & $\begin{array}{c}\text { Weight of } \\
\text { Pancreas }(\mathrm{mg})\end{array}$ & Pancreas & Protein $(\mathrm{mg})$ \\
\cline { 3 - 4 } & $567( \pm 34)$ & $1246( \pm 262)$ & $13( \pm 4)$ \\
$\begin{array}{l}\text { Control } \\
\text { Soybean trypsin } \\
\text { inhibitor }\end{array}$ & $811( \pm 72)$ & $7620( \pm 526)$ & $61( \pm 8)$ \\
$\begin{array}{c}\text { Ovomucoid trypsin } \\
\text { inhibitor }\end{array}$ & $642( \pm 63)$ & $4302( \pm 1280)$ & $40( \pm 16)$ \\
$\begin{array}{c}\text { Bovine pancreatic } \\
\text { trypsin inhibitor }\end{array}$ & $670( \pm 96)$ & $4550( \pm 1637)$ & $31( \pm 14)$
\end{tabular}

TABLE IIIb

ANALYSIS OF INFLUENCE OF TRYPSIN INHIBITORS VS CONTROLS

\begin{tabular}{llll} 
Trypsin Inhibitor & $\begin{array}{l}\text { Amylase } \\
\text { Specific } \\
\text { Activity }\end{array}$ & $\begin{array}{l}\text { Amylase } \\
\text { Capacity }\end{array}$ & $\begin{array}{l}\text { Weight of } \\
\text { Pancreas }\end{array}$ \\
\hline Soybean & $\mathrm{P}<0.0001$ & $\mathrm{P}<0.0001$ & $\mathrm{P}<0.001$ \\
Ovomucoid & $\mathrm{P}<0.01$ & $\mathrm{P}<0.001$ & $\mathrm{P}<0.01$ \\
Bovine pancreatic & $\mathrm{P}<0.02$ & $\mathrm{P}<0.005$ & $\mathrm{P}<0.02$
\end{tabular}

specific activity between the control group and trypsin inhibitor-fed groups is more marked than the assessment based on pancreatic weight alone. There is a significantly greater amylase content in the trypsin inhibitor-fed groups. These results strongly favour the interpretation of a potentiated synthesis of amylase in the pancreases of all groups
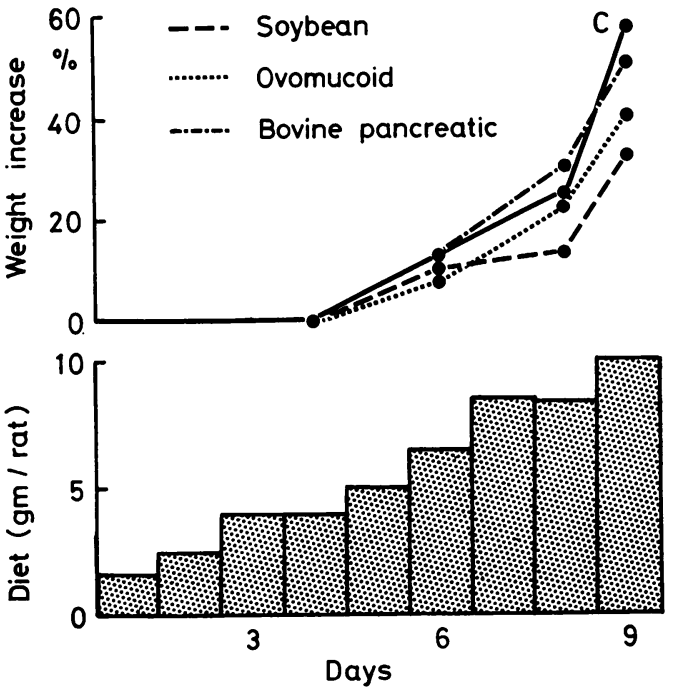

FIG. 2. Growth response curves of rats fed dietary supplements of purified trypsin inhibitors.

fed a dietary supplement of trypsin inhibitor regardless of the source. The potency of these agents (particularly striking in the case of the bovine pancreatic trypsin inhibitor) is exemplified by the low concentration at which they exert their effects.

The mean growth response of the rats in each group calculated as the percentage weight increase over the starting weight is presented in Figure 2. Although the differences between the groups were not significant, the growth rate of each group was inversely related to the pancreatic response to the trypsin inhibitor (Table III). Thus the growth of the soybean inhibitor-fed group was poorest. The ovomucoid inhibitor-fed group was intermediate to that of the control and bovine pancreatic trypsin inhibitorfed group, both of which had a comparable spurt in growth.

INFLUENCE OF VAGOTOMY ON PANCREATIC RESPONSE TO DIETARY TRYPSIN INHIBITORS Five groups each of six rats were chosen, two groups being fed heated and three groups raw soybean supplements. In three groups either the left (one heated and one raw soybean-fed groups) or the right (one raw soybean-fed group) vagus nerve was isolated from the carotid sheath and sectioned just before its entry into the superior mediastinum. A segment of nerve, 2 to $3 \mathrm{~mm}$, was resected on each occasion to prevent spontaneous repair. The remaining two groups (one of each diet) were submitted to a sham operation in which the left vagus nerve was exposed in the neck but not sectioned. 
The animals were observed for 48 hours postoperatively before commencing the diets. All animals displayed similar activity postoperatively and seemed to have been undisturbed by the operation. The rats were permitted to feed ad libitum. The experiment was terminated on the 12th day.

The pancreatic response to the raw soybeansupplemented diet was uninfluenced by either right or left vagotomy (Table IV). All raw soybean-fed groups had significantly larger pancreases $(P<0.001)$. The pancreatic size was consistent between the groups fed the same dietary supplement.

\section{TABLE IV}

INFLUENCE OF VAGOTOMY ON THE PANCREATIC RESPONSE TO THE SOYBEAN-SUPPLEMENTED DIET

\begin{tabular}{lll} 
Diet & Operation & $\begin{array}{c}\text { Weight of Pancreas } \\
(\mathrm{mg} / 100 \mathrm{~g} \text { Body Weight } \\
\pm 1 \text { SD })\end{array}$ \\
\hline Heated & Sham & $323 \cdot 4( \pm 21 \cdot 1)$ \\
Raw & Left vagotomy & $345 \cdot 1( \pm 15 \cdot 5)$ \\
& Sham & $560 \cdot 2( \pm 67 \cdot 8)$ \\
& Left vagotomy & $565 \cdot 6( \pm 48 \cdot 7)$ \\
& Right vagotomy & $541 \cdot 2( \pm 21 \cdot 1)$
\end{tabular}

PANCREATIC EFFECT OF ORAL VS INTRAPERITONEAL BOVINE PANCREATIC TRYPSIN INHIBITOR Three groups of five rats each were used. One group received a daily intraperitoneal injection of bovine pancreatic trypsin inhibitor administered as three divided doses per day over eight days. The volume administered was calculated to contain $0.041 \%(w / w)$ of trypsin inhibitor (related to the total food intake). This averaged $3 \mathrm{ml} / \mathrm{rat} /$ day of undiluted bovine pancreatic trypsin inhibitor. An identical amount was mixed into the daily food supplement of the second group. The control group received intraperitoneal injections of $0.9 \%$ saline in an identical schedule to the first group.

The rats chosen for this experiment had been fed the test diet containing heated soybean supplement for four weeks previously. At the start of the experiment the same feeding schedule employed in experiment 2 was used.

At the time of sacrifice there were no fluid accumulations or peritoneal reaction visible to the naked eye in the bovine pancreatic trypsin inhibitor-injected animals.

The results of this experiment are shown in Table V. Although the amylase capacity of the pancreas was uninfluenced by the bovine pancreatic trypsin inhibitor either ingested or injected, the specific amylase activity in the group receiving the bovine pancreatic trypsin inhibitor orally was significantly greater $(P<0.025)$ than that of the control group. There was no significant difference between the control group and the group which had received the trypsin inhibitor intraperitoneally.

TABLE V

PANCREATIC EFFECT OF ORAL VS. INTRAPERITONEAL BOVINE PANCREATIC TRYPSIN INHIBITOR INJECTIONS ${ }^{1}$

\begin{tabular}{lll} 
Group & Amylase $\left(u \times 10^{3}\right)$ \\
\cline { 2 - 3 } & Pancreas & Protein $(m 8)$ \\
\hline $\begin{array}{l}\text { Control } \\
\begin{array}{l}\text { Trypsin inhibitor } \\
\text { intraperitoneally }\end{array}\end{array}$ & $1060( \pm 419)$ & $18( \pm 7)$ \\
$\begin{array}{l}\text { Trypsin inhibitor } \\
\text { orally }\end{array}$ & $1070( \pm 193)$ & $21( \pm 8)$ \\
\end{tabular}

${ }^{1}$ Results expressed per $100 \mathrm{~g}$ body weight ( $\pm 1 \mathrm{SD}$ ).

\section{DISCUSSION}

The results of these experiments confirm that the oral ingestion of raw soybean or purified trypsin inhibitors from varied sources is associated with enlargement of the pancreas in the rat. In addition, these agents are effective at very low concentrations. Rats have been shown to respond to dietary trypsin inhibitors with a potentiation of enzyme secretion (Lyman, 1957; Lyman and Lepkovsky, 1957; Haines and Lyman, 1961 ; Lyman, Wilcox, and Monsen, 1962) and therefore the pancreatic changes are not due to a reduction in enzyme output. That the enlargement is due to the synthesis of new protein is confirmed by the striking increase in pancreatic amylase capacity and specific activity in the groups fed the dietary supplements of purified trypsin inhibitors (Table III). Siegel, Jacobs, Studer, and Potchen (1968) have demonstrated a twofold increase in the pancreatic incorporation of selenomethionine in rats fed a raw soybean diet for eight days.

Our results show that the liver, another site of very active protein synthesis, was uninfluenced by the raw soybean diet. This confirms the observation of Chernick et al (1948), working with chickens. Microscopic examination of the liver, heart, lungs, thyroid, testes, spleen, kidney, adrenals, and intestine in raw soybean-fed rats is said to be normal (Booth et al, 1960).

The evidence that the poor growth of rats fed trypsin inhibitor-containing diets is secondary to the pancreatic enlargement and consequent outpouring of increased quantities of digestive enzymes is strengthened by the observation that the mean growth rate of each group fed a pure trypsin inhibitor is inversely related to the mean pancreatic size (Fig. 2). Thus the soybean inhibitor-fed group with the largest pancreases had the poorest spurt in growth. The bovine pancreatic trypsin inhibitor-fed 
group with the least pancreatic response grew as well as the control group and the ovomucoid inhibitorfed group was intermediate in both size of pancreas and rate of growth.

Both amylase and protease activity have been demonstrated to increase in the pancreas and intestinal lumen of rats and chickens fed raw soybean diets (Chernick et al, 1948; Lepkovsky, Koike, Sigiura, Dimick, and Furuta, 1966; Guggenheim and Goldberg, 1964). Thus it appears that the stimulatory effect of trypsin inhibitors on the exocrine pancreas is relatively non-selective in that it influences a number of digestive enzymes secreted by the acinar cell.

The question whether the increased enzyme content represents glandular hypertrophy or hyperplasia is unresolved. In the rat both microscopic examination of the pancreas (Booth et al, 1960) and estimation of the DNA content and concentration (Konijn and Guggenheim, 1967) favour hypertrophy rather than hyperplasia. However, in the chicken similar studies suggest hyperplasia (Salman, Pubols, and McGinnis, 1968).

If the vagus played a primary causative role in the pancreatic enlargement, the effect of vagotomy should be either to abolish the response or to produce a response intermediate to that of the unoperated control and raw soybean-fed rats (assuming partial bilateral vagal innervation of the pancreas). The failure of vagotomy to influence the pancreatic response to soybean feeding (Table IV) suggests that the development of an enlarged pancreas is uninfluenced by vagal innervation.

The significantly greater amylase specific activity in rats receiving a low dose of oral bovine pancreatic trypsin inhibitor compared with that in animals receiving intraperitoneal bovine pancreatic trypsin inhibitor suggests the mediation of the gastrointestinal tract in the genesis of this phenomenon. However, it is uncertain as to why the pancreatic response to oral bovine pancreatic trypsin inhibitor in experiment 4 should have been much less marked than in experiment 2 in which a similar dose was ingested. As the average starting weight of the rats in both experiments was the same, and as the dietary schedule was identical, it is thought that the preliminary high protein feeding of the animals in experiment 4 may have masked the effect of very low levels of the bovine pancreatic trypsin inhibitor in the diet. This appeared to be the only major point of difference between the two groups.

By the nature of their physical properties the trypsin inhibitors are highly resistant to tryptic hydrolysis, particularly at the alkaline $p \mathrm{H}$ of the normal duodenal and small bowel contents. It has been shown that, unlike other proteins, the $p \mathrm{H}$ optimum for the tryptic hydrolysis of soybean trypsin inhibitor is around $p \mathrm{H} 3.50$ to 4.50 and declines sharply with rising $p H$ (Finkenstadt and Laskowski, 1966). The naturally occurring trypsin inhibitors used are polypeptide molecules with molecular weights varying from 65,000 (bovine pancreatic trypsin inhibitor) to about 24,000 (soybean inhibitor) and 28,000 (ovomucoid inhibitor). It is highly unlikely that they are absorbed intact.

The complete amino acid composition of the trypsin inhibitors from soybean (Wu and Scheraga, 1962), ovomucoid (Lewis, Snell, Hirschmann, and Fraenkel-Conrat, 1950), and bovine pancreas(Kassell, Radicevic, Berlow, Peansky, and Laskowski, 1963) has been determined. There are no unusual amino acids in the trypsin inhibitor molecule and there is considerable variation in the amino-acid composition of the different inhibitors. As yet, they appear to be united only by their ability to inhibit trypsin. However, acute experiments by Lyman et al (1962) show that even when the trypsin inhibitor is 'neutralized' by titration with trypsin before feeding, it still retains the ability to potentiate the normal pancreatic secretory response to a test meal.

It is unlikely that neutralization of tryptic activity provides some form of negative feedback from the bowel lumen to the pancreatic acinar cell. The trypsin-trypsin inhibitor complex used in the experiment of Lyman et al (1962) could not combine with endogenously secreted trypsin but was still able to potentiate zymogen secretion. In Fig. 2 the growth curve of the bovine pancreatic trypsin inhibitor-fed group is the same as that of the controls despite a significant potentiation of amylase synthesis. This indicates that there must have been sufficient intestinal tryptic activity present adequately to digest the dietary protein.

The available evidence strongly supports the hypothesis that the potentiation of acinar enzyme synthesis is mediated by a humoral agent, presumably a hormone, released by the bowel wall in response to the presence of the trypsin inhibitor in the bowel lumen(Lyman and Lepkovsky, 1957). The potentiated secretion of the zymogen enzymes within 30 minutes of ingesting a test meal containing purified trypsin inhibitor (Lyman et al, 1962), coupled with the observation that the mean weight of the gallbladder of chickens fed a diet containing soybean inhibitor was significantly less than that of a control group (Sambeth, Nesheim, and Serafin, 1967), implicates the pancreozymin-cholecystokinin hormone as a possible mediator of the trypsin-inhibitor-induced pancreatic changes. These observations imply that in addition to its gallbladder-emptying and zymogen-releasing properties this hormone has a specific trophic effect on the pancreatic acinar cell. Pancreatic enlargement 
is thus the consequence of repeated supranormal trophic stimuli.

The pancreatic trypsin inhibitor has been found in a wide variety of avian and mammalian species. The inhibitor has been detected in easily measurable concentrations in the pancreatic juice of those species which have been tested, including man (Haverback, Dyce, Bundy, and Edmondson, 1960), dog (Kalser and Grossman, 1955), and rat (Grossman, 1958). It is usually assumed that the role of the trypsin inhibitor is to inactivate trypsin in the gland tissues. However, our studies suggest that another function of the pancreatic trypsin inhibitor is to provide a positive feedback to the acinar cell from the intestinal mucosa (Fig. 3).

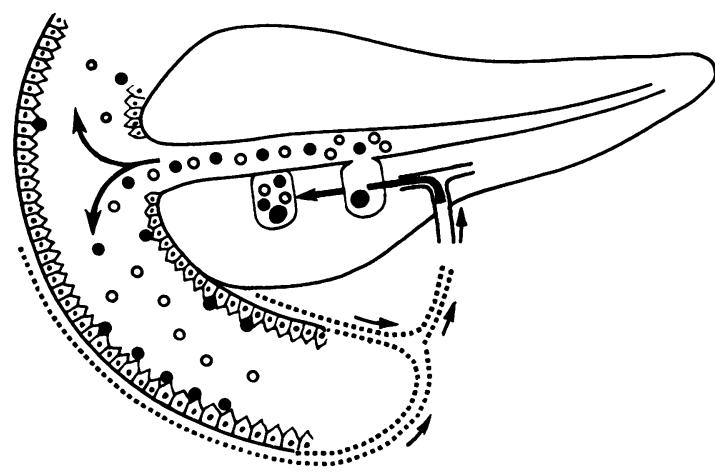

FIG. 3. Suggested actions of endogenously secreted pancreatic trypsin inhibitor. $\mathrm{O}=$ digestive enzymes = pancreatic trypsin inhibitor.

Thus the acinar cell would provide not only the enzymes of digestion but an important stimulus for the repletion of these enzymes. In effect this would mean that the more the acinar cell works the better it works, an observation possibly relevant to the consistent and striking pancreatic atrophy of kwashiorkor (Davies, 1948) and the poor pancreatic exocrine function following duodenal bypass operations (Lundh and Borgström, 1962). The presence of an endogenously secreted pancreatic factor capable of stimulating protein synthesis in the acinar cell would also tend to obscure the significance of experiments involving the injection of agents such as pancreozymin or cholinergic agents (Rothman and Wells, 1967; Webster, 1968). Stimulation of acinar protein synthesis in such experiments could be a result of the increased secretion of pancreatic trypsin inhibitor rather than an independent trophic effect of the injected agent. Future studies in this field should include a consideration of this possible function of endogenously secreted pancreatic trypsin inhibitor.

\section{REFERENCES}

Booth, A. N., Robbins, D. J., Ribelin, W. E., and Deeds, F. (1960). Effect of raw soybean meal and amino acids on pancreatic hypertrophy in rats. Proc. Soc. exp. Biol. (N.Y.), 104, 681-683.

Borchers, R. (1961). Counteraction of the growth depression of raw soybean oil meal by amino acid supplements in weanling rats. J. Nutr., 75, 330-334.

Bowman, D. E. (1944). Fractions derived from soybean and navy beans which retard tryptic digestion of casein. Proc. Soc. exp. Biol. (N.Y.), 57, 139-140.

Chernick, S. S., Lepkowsky, S., and Chaikoff, I. L. (1948). A dietary factor regulating the enzyme content of the pancreas: changes induced in size and proteolytic activity of the chick pancreas by the ingestion of raw soybean meal. Amer. J. Physiol., $155,33-41$.

Davies, J. N. P. (1948). The essential pathology of kwashiorkor. Lancet, 1, 317.

Finkenstadt, W. R., and Laskowski, M. Jr (1966). Unpublished results quoted in:- Ozawa, K., and Laskowski, M. Jr (1966). The reactive site of trypsin inhibitor. J. Biol. Chem., 241, 3955-3961.

Grossman, M. I. (1958). Some properties of trypsin inhibitor of pancreatic juice. Proc. Soc. exp. Biol. (N.Y.), 99, 304-306.

Guggenheim, K., and Goldberg, A. (1964). Endogenous loss of nitrogen originating in the pancreas. In a symposium: The Role of the Gastrointestinal Tract in Protein Metabolism. Edited by H. N. Munro. Blackwell Scientific Publications, pp. 63-80. Oxford.

Haines, P. C., and Lyman, R. L. (1961). Relationships of pancreatic enzyme secretion to growth inhibition in rats fed soybean trypsin inhibitor. J. Nutr., 74, 445-452.

Ham, W. E., and Sandstedt, R. M. (1944.) A proteolytic inhibiting substance in the extract from unheated soybean meal. J. biol. Chem., 154, 505-506.

Haverback, B. J., Dyce, B., Bundy, H., and Edmondson, H. A. (1960). Trypsin, trypsinogen and trypsin inhibitor in human pancreatic juice. Amer. J. Med. 29, 424-433.

Henry, R. J., and Chiamori, N. (1960). Study of the saccharogenic method for the determination of serum and urine amylase. Clin. Chem., 6, 434-452.

Kalser, M. H., and Grossman, M. I. (1955). Secretion of trypsin inhibitor in pancreatic juice. Gastroenterology, 29, 35-45.

Kassell, B., Radicevic, M. , Berlow, S., Peanasky, R. J., and Laskowski, M., Jr (1963). The basic trypsin inhibitor of bovine pancreas. 1. An improved method of preparation and amino acid composition. J. biol. Chem., 238, 3274-3279.

Khayambashi, H., and Lyman, R. L. (1966). Growth depression and pancreatic and intestinal changes in rats force-fed amino acid diets containing soybean trypsin inhibitor. J. Nutr., 89, 455-464.

Klose, A. A., Hill, B., Greaves, J. D., and Fevold, H. L. (1948), Inadequacy of proteolytic enzyme inhibition as explanation for growth depression by lima bean protein fractions. Science, 108 88-89.

Konijn, A. M., and Guggenheim, K. (1967). Effect of raw soybean flour on the composition of rat pancreas. Proc. Soc. exp. Biol. (N.Y.), 126, 65-67.

Kunitz, M. (1945). Crystallization of a trypsin inhibitor from soybean. Science, 101, 668 .

Lepkovsky, S., Koike, T., Sugiura, M., Dimick, M. K., and Furuta, F (1966). Pancreatic amylase in chickens fed on soya-bean diets. Brit. J. Nutr., 20, 421-437.

Lewis, J. C., Snell, N. S., Hirschmann, D. J., and Fraenkel-Conrat, H. (1950). Amino acid composition of egg proteins. J. biol. Chem., 186, 23-35.

Lundh, G., and Borgström, B. (1962). Normal and abnormal digestive function, in Ciba Foundation Symposium: The Exocrine Pancreas. Pp. 259-273. Edited by de Reuck, A. U. S., and M. P. Cameron, Churchill, London.

Lyman, R. L. (1957). The effect of raw soybean meal and trypsin inhibitor diets on the intestinal and pancreatic nitrogen in the rat. J. Nutr., 62, 285-294.

, and Lepkovsky, S. (1957). The effect of raw soybean meal and trypsin inhibitor diets on pancreatic enzyme secretion in the rat. Ibid., 62, 269-284.

-, Wilcox, S. S., and Monsen, E. R. (1962). Pancreatic enzyme secretion produced in the rat by trypsin inhibitors. Amer. $J$. Physiol., 202, 1077-1082.

Melnick, D., Oser, B. L., and Weiss, S. (1946). Rate of enzyme 
digestion of proteins as a factor in nutrition. Science, 103, 326-329.

Miller, G. L. (1959). Protein determination for large numbers of samples. Anal. Chem., 31, 964.

Osbourne, T. B., and Mendel, L. B. (1917). The use of the soybean as a food. J. biol. Chem., 32, 369-387.

Riesen, W. H., Clandinin, D. R., Elvehjem, C. A., and Cravens, W. W. (1947). Liberation of essential amino acids from raw, properly heated, and overheated soybean oil meal. Ibid., 167, 143-150.

Rothman, S. S., and Wells, H. (1967). Enhancement of pancreatic enzyme synthesis by pancreozymin. Amer. J. Physiol., 213, 215-218.

Salman, A. J., Pubols, M. H., and McGinnis, J. (1968). Chemical and microscopic nature of pancreata from chicks fed unheated soybean meal. Proc. Soc. exp. Biol. (N.Y.)., 128, 258-261.
Sambeth, W., Nesheim, M. C., and Serafin, J. A. (1967). Separation of soybean whey into practions with different biological activities for chicks and rats. J. Nutr., 92, 479-490.

Siegel, B., Jacobs, R., Studer, R., and Potchen, E. J. (1968). Attempts to augment pancreatic selenomethionine uptake: Effect of raw soybean diet. J. Lab. clin. Med., 71, 945-947.

Webster, P. D. (1968). Early effect of methacholine on pancreatic RNA synthesis. Amer. J. Physiol., 214, 851-855.

Westfall, R. J., Bosshardt, D. K., and Barnes, R. H. (1948). Influence of crude trypsin inhibitor on utilization of hydrolyzed protein. Proc. Soc. exp. Biol. (N.Y.), 68, 498-500.

Wu, Y. U., and Scheraga, H. A. (1962). Studies on soybean trypsin inhibitor. 1. Physicochemical properties. Biochemistry (Wash.), 1, 698-705. 